\title{
R. D. Anderson \\ European Universities from the Enlightenment to 1914.
}

Oxford: Oxford University Press, 2004. 338 pp.

\section{J.-Guy Lalande}

In this well-researched and well-written book, R. D. Anderson (professor of modern history at the University of Edinburgh) offers a history of European universities in society and in politics, looking at issues such as the relation of universities to the state, academic freedom, and the impact of nationalism.

The first chapters on the eighteenth century emphasize the universities' stagnation (particularly in France and in Great Britain) and their isolation from modern life, with much university teaching having become dubiously relevant to current social needs and intellectually obsolete. The dissolution of the Jesuits in 1773 and, as a result, the growth of state responsibility for education marked a decisive step in secularization, with religion now subordinated to state concerns, though not rejected. The French Revolution and the reaction to it secured the future of the universities, by restoring to them a degree of coherence and uniformity and making them instruments of the forces which shaped the nineteenth century.

The author identifies two turning points - the years 1800 and 1870. The beginning of the nineteenth century is significant for at least three reasons: 1) the influence of Wilhelm von Humboldt, the advocate of the concept of the fusion of research and teaching who, as a Prussian official, played a decisive role in the foundation of the university of Berlin in 1810;2) politically and socially, the year 1800 marks the beginning of the middle-class university and its association with the forces of nationalism, liberalism, and industrialization; and 3) intellectually, the university in 1800 stands for principles - original research, academic freedom, and critical thinking — which had been less prominent in the previous 600 years. After the Restoration, most governments conceived of universities as organs of the state designed to inculcate loyalty and to train its civil servants. Therefore, under the influence of Metternich in the 1820 s and 1830s, the universities, as strongholds of troublesome liberal intellectuals 
and idealistic middle-class youth, became objects of suspicion, supervision, and repression. Professors were, for example, expected to toe the political or religious line or face dismissal.

Largely under the impact of Darwinism and anti-clericalism though, an irreversible shift away from religious to positivist and secular ways of thinking prepared the second caesura of the early 1870s. At that time, not only did the German model of specialized study spread widely outside the German cultural sphere, but political, intellectual, and religious changes secured real autonomy for universities and launched them into a period of dynamic expansion. Anderson outlines the main features of that growth in Germany (where the government used its universities to promote industrial development and where professors believed that their nation had a special cultural mission); in France (where Republicans, with their faith in science as the ally of progress and democracy, spent large amounts of money on higher education); in the British Isles (where imperial needs influenced academic developments in such varied fields as anthropology, oriental languages, tropical medicine, and forestry); in Italy, Spain, and Austria-Hungary (where intellectual elites played a fundamental role in the process of nation-building and where, therefore, the Habsburgs were unable to use the universities to inspire a loyal elite which could hold the dual empire together); and in Russia (where reform and reaction alternated under the last three tsars in a country that, by 1914, had the largest student body in Europe, including the most emancipated set of women students, and where universities produced technical experts, officials, teachers, and professionals who questioned the legitimacy of the autocratic government).

The last three chapters deal with women and universities, student communities and student politics, and the relation between universities and democracy. Women did not easily gain access to the university. The main opposition came from the Catholic Church, with its preference for the domestic ideal of motherhood and its hostility to the idea of careers for women, and from German university professors, the fiercest opponents of women's rights. Women's victory resulted primarily from the persistent campaigning of the women's movement and the changing expectations of families. One of the less studied aspects of university history, the life of students, revolved around the realities of the laboratory and classroom, the social consumption of alcohol, duelling, and politics - the last one, an activity that evolved during the course of the nineteenth century.

"Whereas down to 1848 student politics were characteristically on the left, students being the vanguard of a middle class still excluded from power, by the end of the century they were more commonly on the right" (p. 276). How successful were the universities in their attempts to reach out to educate their respective country, in particular, the working class? Anderson notes that, until secondary education became more widespread, it was not possible for European universities to open themselves to the masses. Nevertheless, "(u)niversity extension was both an attempt to palliate this situation, and a way of avoiding a more radical democratization which would change the nature of university education and challenge the privileges of high culture" (p. 291). Such an initiative, nonetheless, was a sign "that universities before 1914 were 
far from being ivory towers set apart from the social currents of the age" (p. 291). Finally, the author concludes with a summary of the book and a comment on the negative impact of the Great War on universities, noting that their unity "around a set of common academic values was not restored" (p. 293).

A richly comparative and informative survey of the European universities in the eighteenth and nineteenth centuries, this scholarly book, which in places could have been better structured, will interest not only the specialists of the history of higher education, but also those who study the societies and the politics of this eventful period of history. One final note: the 1854 lament of the rector of Lyons, A. A. Cournot, may also intrigue, if not necessarily comfort, those who question the present evolution of the university: " . . amidst the pleasures of civilization, in the presence of the marvelous triumphs of science and industry, the modern world is threatened with invasion by a barbarism of a new kind ... . The time seems past when one studied from the simple love of study or through respect for inherited traditions. Now one studies to pass an examination, to have a degree, and finally to have a job” (p. 116). 